\title{
Designing hypercitizenship methodologically
}

\author{
Andrea Pitasi \\ Andrea Pitasi is PhD by University of Bologna and associated teacher in the same institution, \\ Bologna, Italy, e-mail: andrea.pitasi@gmail.com
}

\begin{abstract}
This paper is essentially epistemological and methodological and is aimed at designing the hypercitizen methodological toolkit. It is not merely through an indicator based approach but also on a modelling based approach and a metatheoretical one (Stepanic et al., 2005: 858). Conceptually, it evolves by reframing the key global changes of our times under the emergence of hypercitizenship from a multidimensional convergence among different kinds of citizenship Pitasi, 2013; Pitasi- Angrisani , 2013): cosmopolitan (Beck, 2006), scientific (Nowotny, 2008), societarian (Donati, 1993), entrepreneurial (I evolved by reinterpreting Audretsch, 2007 who, properly, copes with the "entrepreneurial society" not the entrepreneurial citizenship). The four dimensions are shaped systemically (Luhmann, 1990, 1997) through a social free energy/social entropy coding (Stepanic et al., 2005: 860).
\end{abstract}

Keywords: Hypercitizen, systemic approach, cosmopolitan, Malthus Trap. 


\section{Introduction}

This article positions itself in the emergence of a new lenses to understand the new global changes.

The emergence of hypercitizenship from a multidimensional convergence among different kinds of citizenship:

a) Cosmopolitan (Beck, 2006)

"Cosmopolitanism [...] is a vital theme of European civilization and European consciousness and beyond that of global experience" (Beck, 2006: 2).

b) Scientific (Nowotny, 2008)

"A knowledge based society also increases its production of epistemic things, various kinds of abstract objects, and technical artifacts that are subject to the same rules".

The democratization of scientific expertise is also merely the expansion of the principle of governance that have served the Western liberal democracies well.

Today, science and technology are no longer viewed with awe but are part of everyday life. Mediated by the educational system and the qualifications and certificates people acquire, they determine people's chances for upward social mobility, their working world, and the course of their biographies.

It is thus logical to extend the concept of citizenship to science and technology. "Scientific citizenship comprises rights and duties and asks about both the functions that an expanded concept of citizenship could fulfill in social integration and also the duties that arise from it for citizens as well as for political institutions and administration [...]"(Nowotny, 2008: 20)

c) Societarian (Donati, 1993) 
Implying the capability of citizens and social networks to generate and shape organizations aimed at letting new social forms emerge by linking lobbying and charity.

d) Entrepreneurial ${ }^{1}$

"Europe lacks neither of ideas nor of entrepreneurs, but European history has got two possible perspectives, both discouraging. Those who have ideas will encounter the knowledge filter, facing which they will either give up and nothing will come up of their ideas, or they will find opportunities outside European borders. Either way or the other, Europe loses" (Audretsch, 2007: 162).

This kind of citizenships are also labelled in heideggerian terms as Gegnet/Vollendung (Schuermann, 1987) coding in which "entropy provides (...) the absolute limit of social system development" (Stepanic et al., 2005: 859) while "social free energy F is amount of resources that can be extracted from a social system without significant changes of its structure" (Stepanic et al., 2005:862).

\section{SYSTEMIC THEORETICAL SET}

The hypercitizenship concept is focused on the Durkheimian fact, that systemic communication about key challenges of our times is increasingly meaning communication and public understanding of science and technology for governance and policymaking.

From this point of view, law becomes one of the à la carte products which can be bought by browsing a global "catalogue" (Mundus) surfing on a technological global platform (Globus) of which the Internet is the best metaphor and which can be seen as the most important platform for convergence developments and as a driver of numerous, key, changes. This new media platform is intrinsically cosmopolitan, the concept of cosmopolitan vision is a key contribution by U. Beck (2006).

The author brilliantly adds that:

1 I evolved by reinterpreting Audretsch, 2007 who copes with the "entrepreneurial society", not the entrepreneurial citizenship. 
"what do we mean then by the cosmopolitan outlook? Global sense, a sense of boundarylessness. An everyday, historically, alert, reflexive awareness of ambivalence in a milieu of burying differentiation and cultural contradictions" (Beck, 2006: 3).

As a matter of fact, the cosmopolitan outlook can be featured as follows: as a counter-image to the territorial prison theory of identity, society and politics.

"We can provisionally distinguish five interconnected constitutive principles of the cosmopolitan outlook:

- First, the principle of experience of crisis in world society: the awareness of interdependence and the resulting civilizational community of fear induced by global risks and crisis which overcomes the internal and external boundaries, us and them, the national and the international boundaries;

- Second, the principle of recognition of cosmopolitan differences and the resulting cosmopolitan conflict character and the (limited) curiosity concerning differences of culture and identity;

- Third, the principle of cosmopolitan empathy and of perspective taking and the virtual interchange ability of situations (as both an opportunity and a threat);

- Fourth the principle of the impossibility of living in a world society without borders and there consulting compulsion to redraw old boundaries and rebuild old walls.

- Fifth the mélange principle: the principle that local, national, ethnic, religious and cosmopolitan cultures and traditions interpenetrate, interconnect and intermingle-cosmopolitanism without provincialism is empty, provincialism without cosmopolitanism is blind" (Beck, 2006: 7).

While the mass media often still fall into the methodological nationalism (Beck, 2005), trap which Beck describes as:

the cosmopolitan outlook calls into question one of the most powerful convictions concerning society and politics which find expression in the claim that modern society and modern politics can only be organized in 
the form of national states. Society is equated with society organized in nationally and territorially delimited states. When social actors subscribe to this belief, I speak of a national outlook. When it determines the perspective of the scientific observer I speak of methodological nationalism. (Beck, 2006: 24).

\section{FROM THE THEOREM TO THE INDICATOR SYSTEM}

In this paper, the national outlook is considered a very primitive and cognitive saving form of the most ancient and darkest side of our species evolution and the most elementary tool for trivial common sense to redraw old boundaries and rebuild old walls, boundaries and walls totally meaningless and useless in the global and cosmopolitan age, hypercitizens already practice but still demanded as fetish symbols and dead myths shaped as Linus's blanket by the least civilized and tribal configurations of our species on our planet nowadays.

For example the transnationalization of capitals (Pluess, 2013: 47 ) is pivotal to witness the end of the national outlook nevertheless this transnationalization is possible only after capitals are fully dematerialized into intangible asset portfolios (Dominici- Pitasi, 2012: 33-52).

The national outlook was based on a strong and linear idea of culture, usually the one taught in the history high school lessons in the 1950s "culture" is a very tricky piece of obsoledge (i.e. obsolete knowledge) in the cosmopolitan complexity age in which the current systemic paradigm, after the post-parsonsian shift inspired by Luhmann's "Warum AGIL"? (Luhmann, 1988) may consider "culture" as an enormous constellation of cosmopolitan, memetic recombinations, and reconfigurations on a global scale and no longer the reproduction generation by generation of behaviour, opinions and attitudes shaped by tradition though the ages with no effective chance of meaningful change.

The national look culture based leads both to the Malthus Trap (Malthus, 2004) and to the Obsoledge Trap described by Toffler and Toffler (2006: 111-114).

The transnational flow of migrant labour produces itself the Obsoledge Trap as an increase of circulating labour masses might very unlikely led to a capital improvement. Dematerialization and the transnationalization of capitals leas out of the Malthus and Obsolete traps that is why, as clearly developed by Xiaoying Qi (2012: 707-723) the dema- 
terialized flow par excellence is knowledge and sometimes globalization simply means to let just one concept flow transnationally, redesigning global thinking.

Malthus Trap is founded on a very simple and powerful statement: "population, when unchecked, increased in a geometrical ratio and subsistence for man in an arithmetical ratio" (Malthus, 2004: 21) which means that when the population growth speed (PGS) is faster than the subsistence growth speed (SGS) PGS > SGS, the Malthus Trap is unavoidable and only high speed, radical, reconfiguration technological change can artificially turn upside down this "natural selection" implied by:

\section{PGS $>$ SGS to $S G S>$ PGS}

It is taken for granted that Malthus (1766-1834) could never read Darwin's (1809-1882) "On The Origin of Species" (1859), nevertheless these two authors dramatically influenced what thinking scientifically means: coping with the blindness of evolution which shapes social free energy (SGS > PGS) and social entropy (PGS > SGS) or, in other words, variety (SGS $>$ PGS) and density (PGS $>$ SGS).

As sketched out above, for example, an increasing gagging and a higher birth rate do not represent the problem (aging) and its solution (new-born reduce the average age), they converge paradoxically in a bigger problem: the Malthus Trap.

Likewise, protecting and conserving memory, human heritage while also improving radical scientific and technological reconfigurations do not represent the problem (the old) and its solution (the emerging new) but still represent a bigger problem: the expanding obsoledge as adapting the new to the old simply generates the inflation of the old.

The theorem consists in this: the systemic evolution of mankind on Earth affects individual choices and experiences at the key bifurcation kunhnian revolutionary challenges (Pitasi, 2011a, 2011b,2012a, 2012b, 2012c) and apparently do not in Kuhn's normality as social life is made of cows Ortega y Gasset, 1963).

Individual choices and experiences do not affect systemic evolution with the unique effect of the high resonance traffic jam noise para- 
dox which witnesses that individual influences on systemic evolution are blind.

The traffic jam paradox shows that by interviewing the City Major, the City Traffic Manager, the Municipality Hall Policemen, the individuals sitting in their cars in the jam none of them will tell you that the traffic jam is the outcome of their intentions, ideas, values etc.

The Traffic Jam Paradox can be easily applied to all people supporting an ecological - green vision: none of them will tell you that the Malthus Trap (the Traffic Jam) emerges from their intentions, ideas, values, choices which are focused on a cleaner planet.

Nevertheless, a more ecological social order would dive into the Malthus Trap if ecological choices dramatically influence the rapport between world population demographic growth (WPDG or, as above, PGS) and Evolutionary Resource Reproduction Speed (ERRS or, as above, SGS).

If WPDG/PGS $=$ ERSS/SGS the trap is already open to let our species enter.

If WPDG/PGS > ERSSS/SGS our species is already in the trap.

Once again, in logic-deductive terms, the exit from the trap is an evolutionary systemic bifurcation:

1) the making of a Malthusian vision i.e. high quality eco-bio food in a ridiculous amount which imply million and million people fighting for just "one tomato"; or

2) a convergent tech reconfiguration evolving capital (genetic, information \& more) independently from worked joule which is the logic solution provided by the theorem provided in this essay.

Figure 1 below (designed by the author describes the shape of the bifurcation while Figures 2 and 3 describe some resource reallocation trends on a global scale up to 2050 (cfr. Smith 2011: 178 and 193). Figure 4 pictures Pearce's hypothesis on population crash (Pearce, 2010: 1-2) which would, at a first and misleading glance, falsify the bifurcation trend described above. Taking Pearce's hypothesis for granted (and it cannot be scientifically, of course, moreover he is an environmental journalist not a scientist) it does not falsify the bifurcation, it rather 
seems to describe the mildest "day after" scenario of the option A of the bifurcation itself nevertheless Pearce's works seems to be focus on a technological coteries paribus while from now on to 2050 (and over) the reconfigurational power of convergent technologies is already huge (Harris, 2007; Rose, 2009) and this methodological mistake seems to dramatically reduce Pearce's hypothesis reliability. The bifurcation in which we found a systemic theory of global evolution.

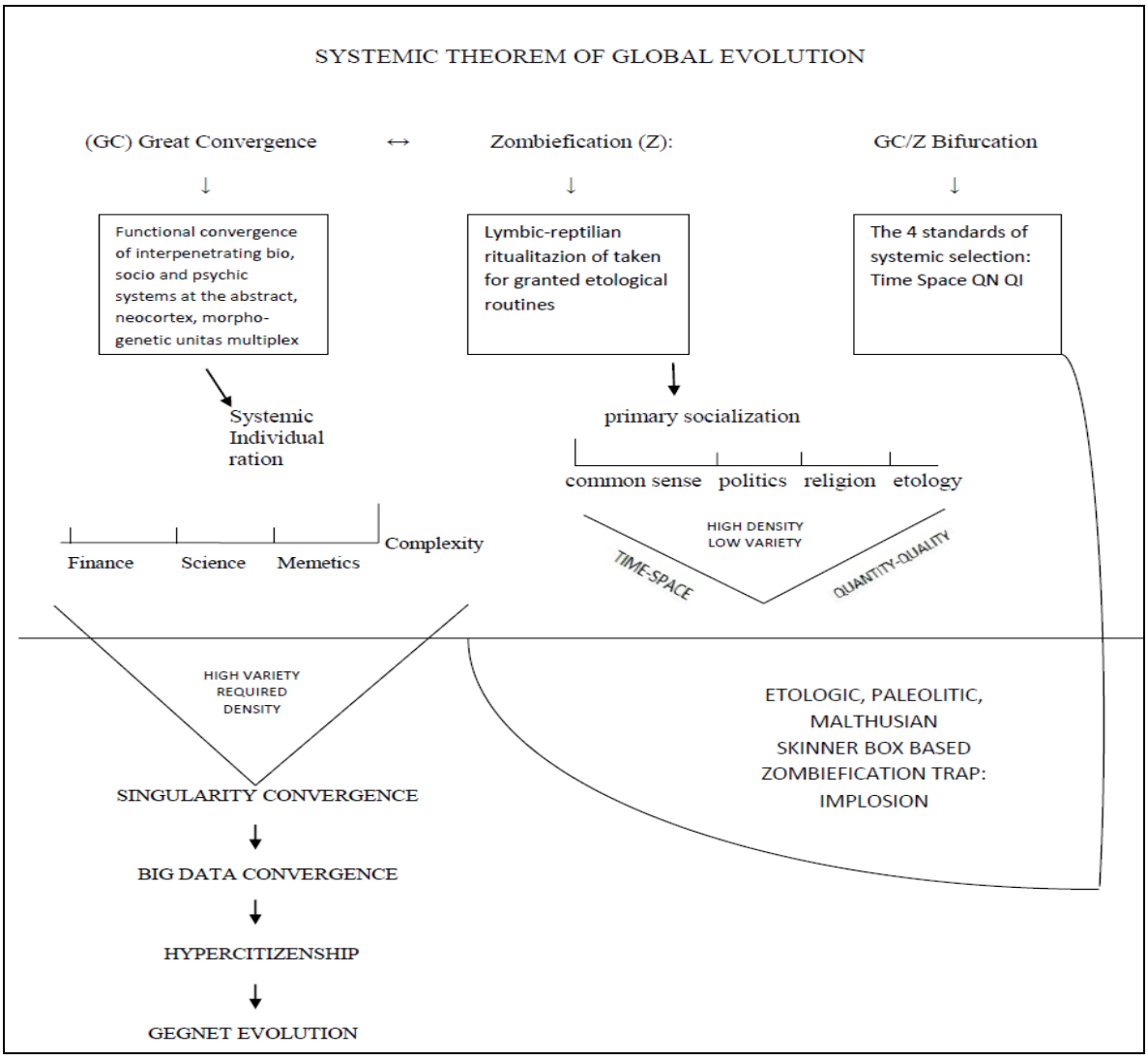

Figure 1. 
Some Common Measure of Economic Globalization, Peacefulness, and Civil Liberties, Relative to the World

\begin{tabular}{|c|c|c|c|c|c|c|}
\hline \multicolumn{2}{|c|}{ Economically globalizing? } & \multicolumn{2}{|c|}{ Peaceful? } & \multicolumn{3}{|c|}{ Political freedoms? Average Score } \\
\hline WSJ/Heritage & EWF & $\begin{array}{l}\text { KOF Globali- } \\
\text { zation }\end{array}$ & GPI & EIUDI & $\begin{array}{c}\text { Freedom } \\
\text { House }\end{array}$ & WSJ/Heritage \\
\hline Denmark & 96 & 91 & 97 & 99 & 97 & Free \\
\hline Canada & 96 & 95 & 96 & 94 & 93 & Free \\
\hline Finland & 91 & 90 & 94 & 94 & 96 & Free \\
\hline Iceland & 92 & 91 & 83 & 97 & 98 & Free \\
\hline Norway & 84 & 84 & 90 & 99 & 99 & Free \\
\hline Sweden & 85 & 77 & 97 & 96 & 99 & Free \\
\hline United States & 97 & 94 & 82 & 42 & 89 & Free \\
\hline Russia & 18 & 28 & 79 & 6 & 36 & not free \\
\hline Germany & 86 & 88 & 89 & 89 & 92 & Free \\
\hline $\begin{array}{l}\text { United King- } \\
\text { dom }\end{array}$ & 94 & 96 & 87 & 76 & 87 & Free \\
\hline Japan & 89 & 81 & 66 & 95 & 90 & Free \\
\hline France & 64 & 68 & 92 & 79 & 86 & Free \\
\hline Brazil & 41 & 32 & 62 & 41 & 75 & Free \\
\hline India & 31 & 45 & 41 & 15 & 79 & Free \\
\hline China & 26 & 34 & 56 & 49 & 19 & not free \\
\hline
\end{tabular}

Table 1. Resource reallocation trends on a global scale up to 2050.

Note: expressed as percentile of all sampled countries in the world

Source: 2009 Index of Economic Freedom, Heritage Foundation, and Wall Street Journal (179 countries); 2008 Economic of the World Index (141 countries); 2009 KOF Index of Globalization (208 countries); 2009 Global Peace Index (144 countries); 2008 Economist Intelligence Unit Democracy Index (167 countries); 2009 Freedom in the World Country Rankings (193 countries). 
Some Population Densities and Trajectories 2010-2050

\begin{tabular}{|c|c|c|c|c|}
\hline Country & $\begin{array}{c}\text { Density } \\
\text { (people/km²) }\end{array}$ & 2010 & 2050 & $\begin{array}{c}\text { Change } \\
\text { (\%) }\end{array}$ \\
\hline India & 369 & $1,214,464,000$ & $1,613,800,000$ & 33 \\
\hline Canada & 3 & $33,890,000$ & $44,414,000$ & 31 \\
\hline United & 33 & $317,641,000$ & $403,932,000$ & 27 \\
\hline \multicolumn{5}{|l|}{ States } \\
\hline Iceland & 3 & 329,000 & 407,000 & 24 \\
\hline Norway & 13 & $4,855,000$ & $5,947,000$ & 22 \\
\hline United & 255 & $61,899,000$ & $72,365,000$ & 17 \\
\hline \multicolumn{5}{|l|}{ Kingdom } \\
\hline Mexico & 57 & $110,645,000$ & $128,964,000$ & 17 \\
\hline Sweden & 21 & $9,293,000$ & $10,571,000$ & 14 \\
\hline Spain & 90 & $45,317,000$ & $51,260,000$ & 13 \\
\hline Brazil & 23 & $195,423,000$ & $218,512,000$ & 12 \\
\hline China & 141 & $1,354,146,000$ & $1,417,054,000$ & 5 \\
\hline Netherlands & 401 & $16,653,000$ & $17,399,000$ & 4 \\
\hline Finland & 16 & $5,346,000$ & $5,445,000$ & 2 \\
\hline Denmark & 127 & $5,481,000$ & 41 & 1 \\
\hline Italy & 199 & $60,098,000$ & & -5 \\
\hline South Korea & 487 & $48,501,000$ & & -9 \\
\hline Germany & 230 & $82,057,000$ & & -14 \\
\hline Russia & 8 & $140,367,000$ & & -17 \\
\hline Japan & 336 & $126,995,000$ & 56 & -20 \\
\hline
\end{tabular}

Table 2 Some Population Densities and Trajectories 2010-2050. 


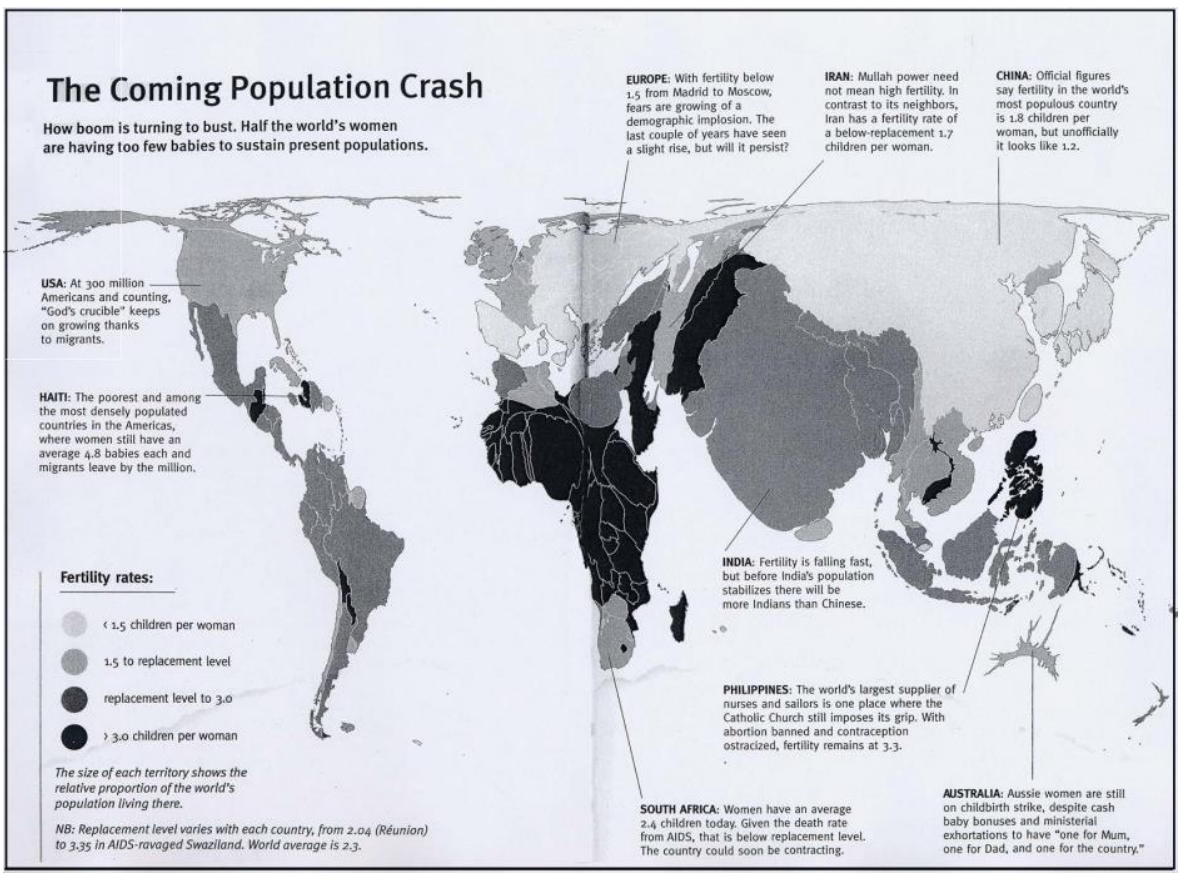

Figure 2

\section{TOWARDS A HYPERCITIZEN INDICATOR SYSTEM}

Hypercitizenship and its four reconfiguration dimensions generate a re-entry of nationalism and provincialism as memes (Dawkins, 1976), among many others, of the Mundus Catalogue recombining memetic sets to be browsed through the Globus by the hypercitizen (which is not necessary a physical person but a set, an unitas multiplex, of decisions, procedures, knowledge and know how systemically shaped and artificially self evolving). The hypercitizen Indicator are:

- CI cosmopolitan index

- SI scientific index

- EI entrepreneurial index

- LI lobbying + charity index

Gegnet VARIETY (= social free energy) Vollendung DENSITY(= social entropy)

CI: Memetic recombination VERSUS Cultural tradition 
SI: Multiple IP streams of income public VERSUS Bureaucratized IP ownership

EI: Multiple streams of Income VERSUS Verticalization of wages

LI: Persistence, strange, abstract VERSUS Insistence, familiar, emotional

An HC indicator system is complex if Variety (V) / Density (D) $>3$

If $\mathrm{V} / \mathrm{D}=3$ or $\mathrm{V} / \mathrm{D}<3$ the system is complicate, not complex thus it is featured by a high paralyzing density of copies and requires high selective (in quantity) and random (in quality, as they are copies) operations.

Methodologically speaking, hypercitizenship (HC) may be formulated a follows:

$\mathrm{HC}=\mathrm{CI}+\mathrm{SI}+\mathrm{EI}+\mathrm{LI}$ which is mathematically a functional equivalent of Macroeconomics fundamental formula GDP $=\mathrm{C}+\mathrm{G}+\mathrm{I}+\mathrm{NX}$ (Constable and Wright, 2011: xvi) thus the four HC dimensions or indexes shape the conceptual frame to construct the HC indicators system.

Nevertheless, GDP's "D " expressed a methodological nationalism inspired by domestic balance while HC is something to be conceptualized, categorized and measured according to global trends and transnational flows: metaphorically, GDP is a black and white photograph, HC is a colour movie.

The construction of an HC indicator system implies a methodological design founded on artificial simulation models framed into logicaldeductive theorems and tested through big data patterns and convergences which for example demonstrate that expansion of the birth rate is not the alternative to the aging trend (Department of Economic and Social Affairs Population Division, 2001) ${ }^{2}$.

Operationalizing concepts into definitions to set the indicator system, requires a logic-deductive formalization shaped as a theorem. The social free energy (Gegnet)/social entropy (Vollendung) coding redesigns the concept - definition- indicator - variable sequence about global evolution.

2 Available at http://www.un.org/esa/population/publications/worldageing19502050/ 
The HC indicator system challenges this loop I call the human heritage bankruptcy but the HC indicator system is linked to a systemic theorem of global evolution which is provided as an exemplary case.

\section{AN EXEMPLARY CASE: HYPERCITIZEN AND THE WORLD HUMAN HERITAGE UNESCO PROGRAM}

The UNESCO Human Heritage Program ${ }^{3}$ provides some eliciting hints for the methodological design of applied hypercitizenship policymaking.

For example, UNESCO is inspired by a key international law principle named common heritage of mankind to underline how human heritage cannot be interpreted through a national outlook and though methodological nationalism. Nevertheless, founding a current global project like this on an international law principle undermines the effective expansion of common heritage of mankind as someway at the international level the specific nations still dramatically matter. As a Human Rights Declaration spin off UNESCO was inspired by Kelsenian positive international law principles as in 1948 (The year of the UN Human Rights Declaration) or so they represented the most abstract level of formalized law nevertheless in our globalized age, supranational law seems emerging and shaping new jurisdictional scenario in which sovereignty belongs to the expansion (of human heritage, in this case) metaphorically, the UNESCO Human Heritage program was and is a great photo album of pictures selected worldwide but in

Sorokinian terms it does not shape a dynamical movie script of cosmopolitan and multicultural interactions yet. Moreover, this program might lead to a couple of paradoxes which do not belong to the UNESCO spirit but might re-shape and e-introduce the national outlook:

First Paradox. The nationalist re-entry: let's imagine a current university whose venue is an ancient, let's say, medieval fortress or monastery somewhere in Europe, let's suppose it applies the UNESCO program to be eligible a common heritage of mankind. The purpose of this application might be twofold and paradoxical: a) to be awarded by the prestigious UNESCO brand b) to underline the great power and

\footnotetext{
Available at: http://whc.unesco.org/en/series/

http://whc.unesco.org/en/series/33/http://whc.unesco.org/
} 
prestige of its own national history in the world thus emphasizing its national supremacy which is not exactly the UNESCO program aim.

Second Paradox. The denial of time evolution: you do not need to be a Nobel Prize to understand that a Medieval fortress was built as a Medieval fortress and its system of gates, chains, towers, bridges, very small and narrow windows and huge walls mirrored a certain vision of the world and a certain military strategy which have nothing to do with a XXI century university requirements (for example huge walls mean no or poor wifi). Yes though the ages the fortress was restored but still a bifurcation:

a) either it was, let's say, completely bombed during WWII and rebuilt as a modern university with a mere external fortress sight but in practice the fortress is no longer a fortress;

b) or the fortress structure is still in and the changes though the years were mere maquillage as a medieval fortress and a XXI century university have no functions in common and thus no "adaptive change" of the structure can evolve viable functions. Consider for example the insurance risk to protect students in a university campus designed to host students and the insurance risk in a medieval fortress more or less turned into a university but originally shaped and designed to kill the external invaders (the students).

The richest and most powerful areas of the planet are not currently those where live in ancient buildings turned into something else, they are rather relatively history poor areas in which the illusion that a great past necessarily means a great present and a great future by reproducing the past is the most evident outcome of the time paradox The UNESCO Human Heritage Program did not intend to lead to these two paradoxes (which are nationalistic closures) but a stronger hypercitizen UNESCO agenda might avoid the program to enter the two paradox loop.

\section{CONCLUSIONS}

Designing hypercitizenship, methodological toolkit implies to evolve systemic strategic thinking both epistemologically and for poli- 
cymaking and this essay dealt with both levels also by providing an exemplary case of the convergence of epistemology and policymaking is pivotal to cope with complex systemic challenges of our times. The next step, in a further essay, will be to enter the technical level of $\mathrm{HC}$ indicators derived from the formula: $\mathrm{HC}=\mathrm{CI}+\mathrm{SI}+\mathrm{EI}+\mathrm{LI}$ discussed in this work.

\section{REFERENCES}

Audretsch D (2007) The Enterpreneurial Society. Oxford: Oxford University Press.

Beck U. (2006) The Cosmopolitan Vision. Cambridge: Polity Press.

Chew M.M. (2014) Rethinking the Relationship Between Intellectuals and Nationalism, Current Sociology, 62:3.

Clapham C. and Nicholson J. (2009) Oxford Concise Dictionary of Mathematics. London - New York: Oxford U. Press.

Constable S. and Wright R.E.(2011) Guide to the 50 Economic Indicators That Really Matter. New York: Harper Business.

Dawkins R (1976) Il gene egoista. Milano: Mondadori.

Dominici G.- Pitasi A. (2012) Reframing the Systemic Approach to Complex Organizations as Intangible Portfolios in: Nuova Atbntide. Rome: Aracne Publishing.

Donati P (1993) La cittadinanza societaria. Rome-Bari: Laterza.

Harris J (2007) Enhancing Evolution. Princeton: Princeton University Press.

N. Luhmann (1988) Warum AGIL? In: Kölner Zeitschrift für Soziologie und Sozialpsychologie.

Luhmann N (1990) Essays on Self Reference. New York: Columbia University Press.

Luhmann N (1996) Social Systems. Stanford: Stanford University Press.

Luhmann N (1997) Die Gesellschaft der Gesellschaft. Frankfurt am Main: Suhrkamp Verlag.

Luhmann N (2010) Soziologische Aufklaerung. Opladen: WestdeutscherVerlag.

Kaufmann S (2000) Investigations. Oxford: Oxford University Press. 
Malthus TR (2004) An essay on the Principle of Population. New York-London: W.W. Norton.

Nowotny H (2008) Insatiable Curiosity-Innovation in a Fragile Future. USA and London: Cambridge.

Ortega y Gasset J (1963) Man and People. New York: Norton.

Pearce F (2010) The On Coming Population Crash. Boston: Beacon Press.

Pitasi A. (2012) Systemic Shifts in Sociology. In: Mancini G and AUTHOR A (eds) Systemic Shifts in Sociology. Saarbruecken: Lambert Academic Publishing.

Paolone G. -Pitasi A. (2013) Comparing Systemic Business Paradigms: Chance, Complexity, Communication and Evolutionary Strategies, Saarbrücken: LAP LAMBERT Academic Publishing.

Pitasi A. (2011a) (et all). Systemic Shift in Sociology. Saarbrücken: LAP LAMBERT Academic Publishing.

Pitasi A. (2012a), The Hypercitizenship Challenge to Methodological Nationalism. REDES - Revista Eletrônica Direito e Sociedade. Centro Universitário La Salle - UniLasalle

Pitasi A. (2012b) What is sociology for? World Futures Journal 68: 221-224.

Pitasi A. (2012c) Hypercitizenship and the Management of Genetic Diversity: Sociology of Law and the Key Systemic Bifurcation Between the Ring Singularity and the Neofeudal Age. World Futures Journal 68: 314-331.

Pitasi A. (2011b) The Hyperhuman World: Legal Systems and Social Complexity. Saarbrücken : LAP LAMBERT Academic Publishing.

Pitasi A. (2013) Epilogue: The Fourth Paradigm Redesigning Evolutionary Complex Systems Of Organizational Communication. In: Mancini G and Angrisani R (eds) Mapping Systemic Knowledge. Saarbrücken: LAP LAMBERT Academic Publishing.

Pitasi A. (2013) Hypercitizenship And The Evolution Of A Global Identity. Journal of Sociological Research 4(2). ISSN:1948-5468.

Plüss C (2013) Migrants Social Positioning and inequalities. The Intersections of Capitals, Locations and Aspirations. International Sociology 28(1).

Rose N (2009) La politica della vita. Turin: Einaudi.

Schürmann R (1987) Heidegger on Being and Active: From Principles to Anarchy. Trans. Christine-Marie Gros. Bloomington and Indianapolis: Indiana University Press. 
Smith LC (2011) The World in 2050. London: Penguin.

Stepanic J and Sabol G and MS Zebec (2005) Describing Social Systems using free social Energy and social entropy. Kybernetes 34(6): 857-868.

Toffler A and Toffler H (2006) Reviolutionary Wealth. London: Doubleday.

Xiaoying Q (2012) A Case Study of Globalized Knowledge Flows: Guanxi in Social Science and Management Theory. Interenational Sociobgy 27(6).

Recebido: 30/09/2014

Received: 09/30/2014

Aprovado: 30/09/2014

Approved: 09/30/2014 